\title{
Sustainability of Climate Change Adaptation Measures in South-South, Nigeria
}

\author{
Osuji, E. E. ${ }^{1 \rtimes(i D)}$ \\ Okwara, M. O. ${ }^{2}$ \\ Essien, U. A. ${ }^{3}$ \\ Agu, C. G. ${ }^{4}$ \\ Oguegbuchulam, M. N. ${ }^{5}$
}

'Department of Agricultural Economics, Michael Okpara University of Agriculture Umudike, Nigeria. Email:osujzemeka2@yahoo.com Tel: +2348037351597

Department of Agricultural Economics, Federal University of Technology Owerri, Imo State, Nigeria

Email: Melissa.okwara@gmail.com Tel: +2347030637556

•Email:essienua@gmail.com Tel: +2348034330650

Department of Cooperative Economics and Management, Institute of Management and Technology Enugu, Nigeria.

"Email:agu chinvere.g@hotmail.com Tel: +2348034033205

${ }^{5}$ Department of Agricultural Extension and Management, Imo State Polytechnic Umuagwo, Owerri, Nigeria.

${ }^{5}$ Email: oguegbuchulammoses@gmail.com Tel: +2348037245403

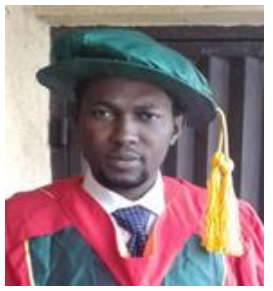

Corresponding Author

\section{Abstract}

The rampaging effects of climate change on Nigeria agriculture cannot be totally undermined, hence, the sustainability of climate change adaptation measures in South-South, Nigeria. A multistage sampling technique was used to select 142 farmers who were interviewed to elicit information bordering on climate change in the area. Data were analyzed using descriptive statistics, ordinary least square multiple regression technique and the scaling model. Results showed that the socio-economic factors investigated influenced the decisiveness of the farmers in embracing adaptive strategies to checkmate the overindulgence of climatic variations in the area. Age of the farmers, educational level, household size, farming experience, farm size, extension contacts were all positive and significant factors. Result also shows that there is increasing rate of temperature, rainfall volume, sunshine hours and number of rainy days and decreasing rate of light intensity and wind. The adaptation techniques of the farmers were classified into highly sustainable adaptation strategies which include; use of pest and disease resistant varieties, use of organic fertilizers, tree planting, early information seeking on climate change etc and slightly sustainable; planting of different crop varieties, mulching, mixed cropping, etc. All the farmers in the area perceived inadequate capital as a major constraint in coping with climate change effects. Hence, this study recommends government all levels to sensitize the crop farmers on the devastating effects of climate change on agriculture as well as provide supports where necessary to cushion its negative impacts.

Keywords: Agriculture, Adaptation, Climate change, Mitigation, Sustainability, Variability, Farmers' perception, Mean scores, OLS regression, Nigeria

Citation | Osuji, E. E.; Okwara, M. O.; Essien, U. A.; Agu, C. G.; Oguegbuchulam, M. N. (2019). Sustainability of Climate Change Adaptation Measures in South-South, Nigeria. Agriculture and Food Sciences Research, 6(1): 120-126.

History:

Received: 12 March 2019

Revised: 8 April 2019

Accepted: 14 May 2019

Published: 4 July 2019

Licensed: This work is licensed under a Creative Commons Attribution 3.0 License (cc) Er

Publisher: Asian Online Journal Publishing Group
Contribution/Acknowledgement: All authors contributed to the conception and design of the study.

Funding: This study received no specific financial support.

Competing Interests: The authors declare that they have no conflict of interests.

Transparency: The authors confirm that the manuscript is an honest, accurate, and transparent account of the study was reported; that no vital accurate, and transparent account of the study was reported; that no vital study as planned have been explained.

Ethical: This study follows all ethical practices during writing.

\section{Contents}

1. Introduction

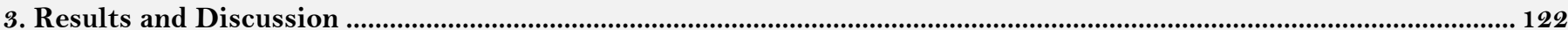

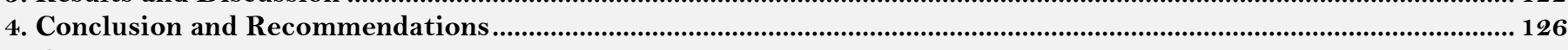

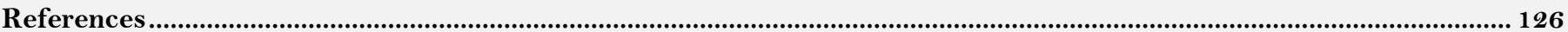




\section{Contribution of this paper to the literature}

This paper affirmed the adaptation measures of crop farmers' to climate change variability using sustainable procedures which enhances farm outputs, yields and productivity, hence ensuring food security and improved income of the crop farmers in Nigeria.

\section{Introduction}

In recent time, climate change is notably one of the major challenges confronting Nigeria Agriculture. Its impacts have been felt both at the national, regional, and local levels.Nigeria is currently under pressure from climate change stresses and its adverse consequences. Many areas in South-South region of Nigeria are recognized as having climates that are among the most variable in the world on seasonal time scales [1]. Floods and droughts occur in these areas times without number leading to famine, hunger and widespread disruption of socio-economic well-being. Nigeria agriculture is largely weather-sensitive and particularly vulnerable to climate change [1]. This vulnerability has been demonstrated by the devastating effects of recent flooding in the South-South region of the Country and the various prolonged droughts that are currently witnessed in some parts of Northern region. Moreover, the over exploitation of land resources (forests), desertification, land degradation and increase in population pose additional threats to climatic variations and changes in Nigeria [2]. Thus, understanding farmers' responses to this climatic variation is very crucial as this will help in designing appropriate sustainable and coping strategies to ameliorate this ugly climatic trend. Also the spatial and erratic rainfall and temperature distribution patterns being experienced in the South-South region of Nigeria have influenced the farm productivity of the farmers leading to loss of food crops, income, low outputs, etc, thereby increasing food insecurity in the region [3]. Conventional approaches to understanding climate change were restricted to identifying and quantifying the potential long-term climate impacts on different ecosystems and economic sectors. Although, essential in depicting general trends and dynamic interactions between the atmosphere, biosphere, land, oceans and ice. Literatures have shown that science driven approach has failed to address the regional and local impacts of climate change and the farmers' abilities to adapt to climate-induced changes [4]. Though, this impact-driven approachhashelped in assessing past and present current vulnerability, existing sustainable adaptation strategies, and how these might be modified to suit recent climatic trend. Adaptation to climate change is a new process for both developed and developing nations and concrete experience in applying an integrated approach to adaptation is limited [5]. Adaptation is a process through which societies make themselves able to cope with future uncertainties. Adapting to climate change entails taking the right measures to reduce the negative effects of climate change (or exploit the positive ones) by making the appropriate adjustments and changes. However, sustainable adaptation measures in South-South region of Nigeria range from technological options such as improved farming methods, timely cultivations and reducing usage of water during drought seasons. Other strategies include early warning systems for extreme events, better water management, improved risk management, various insurance options and biodiversity conservation. Considering the speed at which climate is changing due to global temperature rise, it is obvious that the vulnerability of developing countries to climate change is increasing and their capacity to adapt has also increased [6]. Both mitigation and adaptation measures must be seriously pursued to tackle the climate change problem and to create an effective and inclusive international climate change regime. Sensitivity to the issue of adaptation has grown over the last couple of years, particularly after the IPCC (Intergovernmental Panel on Climate Change) and TAR (Third Assessment Report) [7]. Adaptation has now emerged as an urgent policy priority, prompting action both within and outside the climate change negotiations [8]. Adaptation calls for natural resource management, buttressing food security, development of social and human capital and strengthening of institutional systems. Such processes, besides building resilience of farmers, communities, regions and countries to all shocks and stresses, including climate variability and changes are good development practice in themselves. However, the risks associated with climate change call for a broad spectrum of policy responses and strategies at the local, regional, national and global level. Hence the essence of this study which seeks to examine the sustainability of climate change adaptation measures in South-South, Nigeria.

\section{Materials and Methods}

This study was carried out in Rivers State, Nigeria due to the devastating effects of climate change in the area. It has a total land mass of $11,077 \mathrm{Sq} \mathrm{km}$ and is located on latitudes $4032^{\prime}$ and 50 53' North and longitudes 70 25' and $8025^{\prime}$ east of the equator. It is bounded on the South by the Atlantic Ocean, to the North by Imo and Abia States, to the East by Akwalbom State and to the West by Bayelsa and Delta and States. The inland part of Rivers State consists of tropical rainforest; towards the coast the typical Niger Delta environment features many mangrove swamps. Temperature range is between $23-31^{\circ} \mathrm{C}$ and vegetation found in the State includes the saline water swamp, mangrove swamp and the rain forest. Major seasons are the dry (November-February) and wet seasons (October - March). The climatic and soil condition of the study area favour the extensive production of various food crops such as yam, cassava, maize, vegetables plantains and cocoyam. Multistage sampling technique was used to select two Local Government Areas each out of the three senatorial zones of the State. Three Communities were picked from each of the selected Local Government Areas hence; ten registered crop farmers were randomly selected from the various Communities giving a sample size of 180 farmers. Questionnaire, in-depth scheduled interviews and direct personal field interactions were used to extract information from the respondents but after sorting out the data instruments, only 142 questionnaires were found useful for data analysis. Data were analyzed using descriptive statistics such as the (mean, frequency counts, relative frequency), ordinary least square multiple regression technique as well as the scaling model. In this study, 4 functional forms were fitted into the Ordinary Least Square Multiple Regression Model expressed as follows;

$$
\mathrm{Y}=\mathrm{F}\left(\mathrm{X}_{1}, \mathrm{X}_{2}, \mathrm{X}_{3}, \mathrm{X}_{4}, \mathrm{X}_{5}, \mathrm{X}_{6}, \mathrm{X}_{7}, \mathrm{X}_{8}+\mathrm{e}\right)
$$

Linear function

$$
\mathrm{Y}=\mathrm{b}_{0}+\mathrm{b}_{1} \mathrm{X}_{1}+\mathrm{b}_{2} \mathrm{X}_{2}+\mathrm{b}_{3} \mathrm{X}_{3}+\mathrm{b}_{4} \mathrm{X}_{4}+\mathrm{b}_{5} \mathrm{X}_{5}+\mathrm{b}_{6} \mathrm{X}_{6}+\mathrm{b}_{7} \mathrm{X}_{7}+\mathrm{b}_{8} \mathrm{X}_{8}+\mathrm{e}
$$


Semi-log function

$\mathrm{Y}=\mathrm{b}_{\mathrm{o}}+\mathrm{b}_{1} \log \mathrm{X}_{1}+\mathrm{b}_{2} \log \mathrm{X}_{2}+\mathrm{b}_{3} \log \mathrm{X}_{3}+\mathrm{b}_{4} \log \mathrm{X}_{4}+\mathrm{b}_{5} \log \mathrm{X}_{5}+\mathrm{b}_{6} \log \mathrm{X}_{6}+\mathrm{b}_{7} \log \mathrm{X}_{7}+$

$\mathrm{b}_{8} \log \mathrm{x}_{8}+\mathrm{e}$

Double- $\log$ function

$$
\log \mathrm{Y}=\mathrm{b}_{\mathrm{o}}+\mathrm{b}_{1} \log \mathrm{X}_{1}+\mathrm{b}_{2} \log \mathrm{X}_{2}+\mathrm{b}_{3} \log \mathrm{X}_{3}+\mathrm{b}_{4} \log \mathrm{X}_{4}+\mathrm{b}_{5} \log \mathrm{X}_{5}+\mathrm{b}_{6} \log \mathrm{X}_{6}+\mathrm{b}_{7} \log \mathrm{X}_{7}+
$$

$\mathrm{b}_{8} \log \mathrm{X}_{8}+\mathrm{e}$

Exponential function

$\log Q=b_{0}+b_{1} x_{1}+b_{2} x_{2}+b_{3} x_{3}+b_{4} x_{4}+b_{5} x_{5}+b_{6} x_{6}+b_{7} x_{7}+b_{8} x_{8}+$ e eqn. (5)

Where;

$\mathrm{Y}=$ ith ratio of adaptation strategies/techniques of farmers'

$\mathrm{X}_{1}=$ Age (years)

$\mathrm{X}_{2}=$ Gender $($ Male $=1 ;$ Female $=0)$

$\mathrm{X}_{3}=$ Marital status (Married $=1$; Single $=0$ )

$\mathrm{X}_{4}=$ Household size (number of pesons)

$\mathrm{X}_{5}=$ Level of education (years spent in school)

$\mathrm{X}_{6}=$ Farming experience (years)

$\mathrm{X}_{7}=$ Farm size (hectare)

$\mathrm{X}_{8}=$ Extension contacts (number of contacts)

$\mathrm{e}=$ Error term

\section{Results and Discussion}

3.1. Socio-Economic Factors Influencing Farmers' Adaptation to Climate Change

Table 1; below shows the socio-economic factors influencing adaptation of farmers to climate change. Majority of the farmers aged between 41-50 years with a corresponding mean age of 50 years. This implies that the farmers are not too old to embrace adaptive measures in mitigating climate change incidence. Age is known to influence adaptive capabilities of farmers as it relates to climate change outcomes [9]. Female farmers in the area accounted for $54.2 \%$ as against $45.8 \%$ of male farmers.

\begin{tabular}{|c|c|c|c|}
\hline Socio-Economic Factors & Frequency & Relative Frequency & Mean \\
\hline Age & & & 50 \\
\hline $31-40$ & 24 & 17.0 & \\
\hline $41-50$ & 64 & 45.1 & \\
\hline $51-60$ & 20 & 14.1 & \\
\hline 61 and above & 34 & 24.0 & \\
\hline \multicolumn{4}{|l|}{ Gender } \\
\hline Male & 65 & 45.8 & \\
\hline Female & 77 & 54.2 & \\
\hline \multicolumn{4}{|l|}{ Marital Status } \\
\hline Single & 44 & 31.0 & \\
\hline Married & 98 & 69.0 & \\
\hline Household Size & & & 7 \\
\hline $1-5$ & 45 & 31.7 & \\
\hline $6-10$ & 93 & 65.5 & \\
\hline $11-15$ & 4 & 2.8 & \\
\hline 15 and above & 0 & $\mathrm{O}$ & \\
\hline Educational Level & & & 7 \\
\hline $\mathrm{O}$ (No formal) & 31 & 21.8 & \\
\hline $1-6$ & 36 & 25.3 & \\
\hline $7-13$ & 67 & 47.1 & \\
\hline 14 and above & 8 & 5.6 & \\
\hline Farming Experience & & & 10 \\
\hline $1-5$ & 19 & 13.4 & \\
\hline $6-10$ & 59 & 41.5 & \\
\hline $11-15$ & 44 & 31.0 & \\
\hline 16 and above & 20 & 14.1 & \\
\hline Farm Size (Ha) & & & 2 \\
\hline Less than 1 & 55 & 38.7 & \\
\hline $2-3$ & 81 & 57.0 & \\
\hline $4-5$ & 4 & 2.8 & \\
\hline 6 and above & 2 & 1.4 & \\
\hline Extension Contacts & & & 10 \\
\hline $1-5$ & 41 & 28.9 & \\
\hline $6-10$ & 46 & 32.4 & \\
\hline $11-15$ & 39 & 27.5 & \\
\hline 16 and above & 16 & 11.3 & \\
\hline Total & 142 & 100 & \\
\hline
\end{tabular}

This implies the dominance of female farmers in the area and support the claim that women engaged more in climate change mitigation. African women are seen as climatic change agents and thus, contribute more in 
domestic food production [10]. Again, married farmers dominated the entire area accounting for $69 \%$ with logical implication that marriage contributes to household size which plays a major role in combating climate change. Furthermore, marriage is sine qua non to family labour which helps in adapting to climatic conditions. Almost $66 \%$ of the farmers had household sizes which range from 6-10 with a mean household size of 7 . This implies that farmers tend to utilize more labour which is indispensable in mitigating climate change occurrences. It is believed that the higher the household size, the higher the farmers' adaptation to climate change since more hands will be needed to mitigate the negative effects of climate change. Large sizes of households encourage adaptive potentials of farmers as well as position them for improved outputs [11]. The study revealed the mean educational level of the farmers as 7 years which implies that the farmers attempted post primary education which exposes them to innovative ideas in handling climatic outcomes. Education is believed to equip farmers with the right knowledge needed to overcome adverse climatic changes and weather conditions Farmers in the area had 10 years of farming experience. Farming experience instills in farmers the ability to cope with adverse climatic conditions and adaptive measures. Farming experience enhances farmers' knowledge and understanding of climatic events and conditions as well as equips farmers to adapt favorably to changing climate. Experienced farmers are more skilled and organized in handling climatic issues and variations. About $57 \%$ of the farmers had farm sizes ranging between 2 to 3 hectares with a mean farm size of 2 hectares. Small farm sizes influences the perception of farmers in mitigating climatic change. Farm sizes in rural areas is often fragmented and scattered making it unsuitable to adopt adaptation strategies/measures especially crop rotation, etc to mitigate climatic effects. Farmers in the area had reasonable extension contacts $(10$, contacts/annum). This implies that farmers in the area were exposed to various adaptation strategies by the extension agents that visited the area. Extension contacts expose rural farmers' to innovative ideas and adaptation techniques and further equip them with a good understanding and knowledge of climatic changes and variations which helps in mitigating adverse climatic conditions.

\subsection{Farmers' Sources of Information on Climate Change Variability}

Table 2 reveals the sources of information on climate change variability available to the farmers. From the Table, Extension contacts proved to be the major source of information to the farmers in the area. Extension agents' are information channels and change agents. They expose farmers to adaptive measures used in mitigating adverse climatic variations. About $89 \%$ of the farmers learnt about climate change through the viewing of television and listening to radio. These medium offers a wider dissemination of information on climate change variations. While less than $86 \%$ of the farmers learnt about the effects of climate change through their friends/relatives. Farmers often learn new things much faster and much easier from their colleagues (friends/relatives). $73 \%$ and $47 \%$ of the farmers got to know of climate change through the non-governmental organizations (NGO's) as well as other government agencies. In recent times non-governmental organizations and government agencies have simultaneously engaged in the dissemination of information bordering on climate change variations [12]. Also $18 \%$ of the crop farmers knew about climate change through the print media. Print media such as (newspapers, magazines, literatures, journals, articles, dossiers on climate change, etc) helps to diffuse information on climatic variation and / or conditions prevalent in an area, while $33 \%$ and $70 \%$ of the crop farmers discovered of climate change through seminars/conferences and local workshops. These medium exposes farmers to information bordering on climate change. Farmers who are privileged to attend seminars and workshops are better informed on climatic variations as well as on other agricultural packages and concerns. Furthermore, other sources of information on climate change variability indicated by the farmers include; self observations and personal experience (55\%), interactions with other enlightened farmers (64\%), internet/web services $(16 \%)$ and others $(14 \%)$. These medium are effective and proven sources of information gathering of farmers.

Table-2.Farmers' Source of Information on Climate Change Variability.

\begin{tabular}{l|c|c}
\hline Sources of Information & **Frequency & Relative Frequency \\
\hline NGO's & 103 & 72.5 \\
\hline Government Agency & 67 & 47.2 \\
\hline Self-observation and experience & 78 & 54.9 \\
\hline Interaction with enlightened farmers & 91 & 64.1 \\
\hline Radio & 126 & 88.7 \\
\hline Television & 129 & 90.8 \\
\hline Friends/Relatives & 124 & 87.3 \\
\hline Extension Agents & 132 & 92.5 \\
\hline Seminars/Conferences & 47 & 33.1 \\
\hline Internet/Web & 23 & 16.2 \\
\hline Local Workshops & 99 & 69.7 \\
Print Materials & 25 & 17.6 \\
Others & 20 & 14.1 \\
\hline Source: Field survey, (2018)**Multiple Responses Recorded & &
\end{tabular}

\subsection{Farmers' Perception of Climate Change Variability}

Table 3 shows farmers' perception of climate change variability in the area. A mean index of 2.0 was estimated using scaling techniques. Results show that there is increasing rate of temperature (2.41), rainfall volume (3.05), sunshine hours (2.45), and number of rainy days (2.91). This implies a high variability occurrence of climate change prevalent in the area. The standard deviation values of the aforesaid climate variables were all less than 1.O., except rainfall volume which implies that the volume of rainfall exceeded its previous records in the area. Furthermore, farmers in the area perceived a decreasing rate of light intensity and wind while relative humidity and soil $\mathrm{Ph}$ in the area remained unchanged. This further indicates vagaries of climatic atmospheric conditions dominant in the area. Hence these atmospheric variations undoubtedly influenced agricultural operations in the area. Farmers in a bid to 
maximize farm utility engaged in multiple adaptation strategies to cushion the negative effects of climate change variations [13].

Table-3.Farmers' Perception of Climate Change Variability.

\begin{tabular}{l|c|c|c}
\hline Climatic/Soil Index & Mean Score & S.D & Remark \\
\hline Temperature & 2.41 & 0.96 & Increasing \\
\hline Rainfall volume & 3.05 & 1.88 & Increasing \\
\hline Sunshine hours & 2.45 & 0.82 & Increasing \\
\hline Number of rainy days & 2.91 & 0.98 & Increasing \\
\hline Humidity & 2.00 & 0.77 & Unchanged \\
\hline Light intensity & 1.93 & 0.09 & Decreasing \\
\hline Wind & 1.81 & 1.58 & Decreasing \\
\hline Soil PH & 2.00 & 0.59 & Unchanged \\
\hline Note: $\mathrm{M}>2.0=$ Increasing, $\mathrm{M}<2.0=$ Decreasing, and $\mathrm{M}=2.0=$ Unchanged. & &
\end{tabular}

Source: Field survey, (2018)

\subsection{Farmers' Adaptation Strategies in Mitigating Climate Change Variability}

Table 4 shows the adaptation strategies/techniques practiced by the farmers in mitigating climate change effects. These adaptation techniques are classified into degrees of sustainability with respect to the mean score obtained. The highly sustainable adaptation strategies mostly practiced by the farmers include; use of pest and disease resistant varieties (3.90), use of organic fertilizers (3.01), tree planting (2.67), early information seeking on climate change (2.25), soil conservation practices (2.09), cover cropping (2.90), increase use of family labour (2.01), cultivation of early maturing varieties' (1.99), early and late planting (1.98), regular weeding to avoid breed of insect pests (1.98), use of improved crop varieties (1.54) and insurance options (1.90). Use of pest and disease resistant varieties are widely used by farmers in combating the adverse effects of climate change. Farmers' often make good use of crop varieties that are free from pest and disease infestations in mitigating climatic variation. Organic fertilizers are often used by farmers to checkmate adverse climatic conditions as well as replenish and / or restore the fertility of the soil probably due to easy accessibility and cheap source of the manure [Q]. The planting of trees is a vital adaptive measure used to withstand uncertainties in regards to climatic change. Trees are planted to prevent undue destruction of the vegetative cover of the soil and other nefarious activities of climate change. Early information seeking on climate change enables farmers to avert the consequences of climate change on time and also forestall adverse effects of climatic variations. Soil conservation practices such as cover cropping helps to prevent unforeseen variations of climatic change. Cover cropping is an adaptive technique that increases soil fertility which in turn enhances the productivity of the farmers [14].Family labour improves agricultural activities in the sense that more hands are hired to facilitate farm operations. Cultivation of early maturing varieties is a widely mitigation strategies mostly adopted by farmers in coping with the demands of changing climates. This strategy assist farmer to improve on crop yield and avert ugly incidences of climate change. Furthermore, farmers also engaged in early and late planting to checkmate variations of climate change. Early and late planting is frequently practiced by crop farmers to mitigate and overcome excessive incidence of climate change.

Table-4.Farmers' Adaptation Strategies in Mitigating Climate Change Variability

\begin{tabular}{|c|c|c|c|}
\hline Farmers'Adaptation Strategies/Techniques & Mean Score & S.D & Remark \\
\hline Tree planting (Afforestation) & 2.67 & 0.76 & Highly sustainable \\
\hline Soil conservation practices & 2.09 & 0.98 & Highly sustainable \\
\hline Planting different crop varieties & 1.45 & 0.62 & Slightly sustainable \\
\hline Early and late planting & 1.98 & 0.88 & Highly sustainable \\
\hline Use of improved varieties & 1.54 & 0.67 & Highly sustainable \\
\hline Irrigation practices & 1.23 & 2.09 & Slightly sustainable \\
\hline Improved farming methods & 1.46 & 0.40 & Slightly sustainable \\
\hline Use of organic fertilizers & 3.01 & 0.58 & Highly sustainable \\
\hline Crop-livestock diversification & 1.05 & 0.69 & Slightly sustainable \\
\hline Mixed cropping & 1.44 & 0.87 & Slightly sustainable \\
\hline Crop rotation & 1.43 & 2.98 & Slightly sustainable \\
\hline Mulching & 1.45 & 0.66 & Slightly sustainable \\
\hline Change in planting dates & 1.67 & 0.54 & Highly sustainable \\
\hline Cultivation of early maturing varieties & 1.99 & 0.61 & Highly sustainable \\
\hline Cover cropping & 2.90 & 0.87 & Highly sustainable \\
\hline Relocation of farm lands & 1.05 & 0.63 & Slightly sustainable \\
\hline Increase use of family labour & 2.01 & 0.84 & Highly sustainable \\
\hline Use of pest and disease resistant varieties & 3.09 & 0.09 & Highly sustainable \\
\hline Avoidance of farm areas susceptible to flooding & 1.40 & 0.59 & Slightly sustainable \\
\hline Regular weeding to avoid breed of insects pests & 1.98 & 0.77 & Highly sustainable \\
\hline Breeding of drought and heat resistant crop varieties & 1.35 & 0.60 & Slightly sustainable \\
\hline Avoidance of deforestation & 1.09 & 0.64 & Slightly sustainable \\
\hline $\begin{array}{l}\text { Early information seeking/warning on climate change } \\
\text { Improved risks management }\end{array}$ & 2.25 & 0.73 & Highly sustainable \\
\hline Insurance option & 1.21 & 0.91 & Slightly sustainable \\
\hline Better water management & 1.90 & 0.31 & Highly sustainable \\
\hline \multirow[t]{2}{*}{ Biodiversity conservation } & 1.01 & 0.57 & Slightly sustainable \\
\hline & 1.45 & 0.69 & Slightly sustainable \\
\hline
\end{tabular}

保

Source: Field survey, (2018). 
Regular weeding on the farm is usually carried out to avoid breeding of insects' pests which alters yields on the farm. Use of improved crop varieties helps farmers to reduce losses and improve the productivity of the land. Farmers often use improved crop varieties to avert total crop failure as a result of the changing climate. In recent times, farmers' insure their farmlands and other valuable farm assets to cushion the negative effects of certain uncertainties emerging from climate change. However, the values obtained of the standard deviations in highly sustainable techniques are all less than one, implying that these adaptive techniques do not vary much with the mean scores estimated hence agrees with the result. Similarly, quite a number of the adaptive measures of the farmers were slightly sustainable and these include; planting of different crop varieties (1.45), mulching (1.45), mixed cropping (1.44), avoidance of farm areas susceptible to flooding (1.40), crop rotation (1.43), irrigation practices (1.23), breeding of drought and resistant crop varieties (1.35), Improved farming methods (1.46), avoidance of deforestation (1.09), crop-livestock diversification (1.05), improved risk management (1.21), insurance options (1.90), better water management, relocation of farmlands (1.05) biodiversity conservation (1.45). Of all the adaptive measures that were slightly sustainable only crop rotation and irrigation practices had a high standard deviation signifying a slight variation from the mean scores obtained, probably due to the technicalities associated with these two techniques.

\subsection{Factors' Influencing Farmers Adaptation to Climate Change Variability}

Table 5 reveals the factors influencing farmers' adaptation to climate change variability. Four functional forms of the ordinary least square multiple regression models were fitted in to assess the factors influencing farmers' adaptation to climate change variability in the area. From the result, The Linear functional form was isolated as the lead equation based on the significance of the explanatory variables, highest $\mathrm{R}^{2}$, and F-statistics and was further used for interpretations. The Coefficient of multiple determination $\left(\mathrm{R}^{2}\right)$ was0.8722. This suggests that about $87 \%$ of the total variation in the endogenous variable were explicitly explained by the exogenous variables investigated. The $\mathrm{F}$-value of $42 \%$ further indicated the fitness of the model. The coefficient of age was positive and significant at $5 \%$ level. This implies that as farmers' advances in age, their ability to adapt to climatic changes increases per time.

This is probably as a result of accumulated farming experiences which leverage their acceptance of adaptive techniques to forestall the despicable incidence of climate change [15]. Household size was also positive and significant at $5 \%$ level. This reveals increase in family labour via expansion of household size. As household size increases, more family labour (more hands) is effectively utilized in mitigating the negative impacts of climate change in the area. The coefficient of level of education was significant at $1 \%$ level and was positive too. This implies that education increases the farmers' knowledge and understanding of climate change and as well as reposition the farmers' mindset in adopting new scientific strategies with respect to combating the incidence of climatic variations. The farming experience of the farmers has a positive relationship, and was significant at $5 \%$ level. This implies that $1 \%$ increase in farming experience of the farmers will lead to a corresponding increase in farmers ability in adapting to climatic changes. Farming experience enhances the farmers' drive in adapting to climatic changes which ensures improved farrn outcomes.

Farm size was also significant at $1 \%$ level having a positive sign. This implies that larger farm sizes motivate farmers to practice adaptive strategies that repel climatic changes. Farmers with large farm sizes are likely to adopt anti climatic techniques than farmers with lesser farm sizes. The coefficient of extension contacts was positive and also significant at $5 \%$ level. This further implies that $1 \%$ increase in extension contacts of the crop farmers will equally lead to a corresponding increase in adaptative abilities of the farmers. The relevance of extension agents in championing the impacts of climate change can not be undermined as they are evidently known as change agents in exposing the farmers to understand the phenomenon of climate change and adaptive ways to mitigate and combat its adverse effects[16]. However, other variables such as gender and marital status was not significant at all and this might be due to statistical errors encountered during the process of investigation.

Table-5. Factors Influencing Farmers' Adaptation to Climate Change Variability.

\begin{tabular}{c|c|c|c|c}
\hline Variables & Coefficients & t-Values & Std. Error & Sign. Levels \\
\hline Age $\left(\mathrm{X}_{1}\right)$ & 2.0935 & 2.5091 & 0.8343 & $* *$ \\
\hline Gender $\left(\mathrm{X}_{2}\right)$ & 1.8853 & 1.0981 & 1.7168 & $\mathrm{NS}$ \\
\hline Marital status $\left(\mathrm{X}_{3}\right)$ & 0.3657 & 1.0071 & 0.3631 & $\mathrm{NS}$ \\
\hline Household size $\left(\mathrm{X}_{4}\right)$ & 0.9074 & 2.5671 & 0.3534 & $* *$ \\
\hline Level of education $\left(\mathrm{X}_{5}\right)$ & 2.5680 & 4.0912 & 0.6276 & $* * *$ \\
\hline Farming experience $\left(\mathrm{X}_{6}\right)$ & 0.3785 & 2.6109 & 0.1449 & $* *$ \\
\hline Farm size $\left(\mathrm{X}_{7}\right)$ & 1.0987 & 3.0902 & 0.3555 & $* * *$ \\
\hline Extension contacts $\left(\mathrm{X}_{8}\right)$ & 1.9041 & 2.6710 & 0.7128 & $* *$ \\
\hline Constant & 2.7862 & 1.2091 & 2.3043 & $\mathrm{NS}$ \\
\hline $\mathrm{R}$ & 0.8722 & & & \\
\hline $\mathrm{F}-\mathrm{value}$ & 41.631 & & & \\
\hline $\mathrm{N}$ & 142 & & & \\
\hline
\end{tabular}

Source: Field survey, (2018).

\subsection{Farmers' Perceived Constraints to Climate Change Variability}

Table 6 shows the farmers' perceived constraints to climate change variability. From the Table, 100\% of the farmers; which implies that all the farmers in the area perceivedinadequate capital as a major constraint to climate change? This could be true because capital is majorly required to acquire a piece of land, purchase farm inputs, hire labourers, and above all practice anti climatic adaptive strategies and/ or techniques [2]. About $90 \%$ of the farmers indicated inadequate farmlands and inadequate information on climate change. Most times, inadequate farmlands and information on climate change makes it difficult for farmers to adopt climatic techniques.

Again, $92 \%$ and $87 \%$ of the farmers indicated land fragmentations and erosion issues as their major constraints. This duo makes it practically impossible for farmers to adopt climatic adaptive techniques. Furthermore, other farmers in the area indicated high cost farm inputs (62\%), constant deforestation $(70 \%)$, inadequate extension 
agents $(16 \%)$, high cost of labour $(24 \%)$ and long distance of farmlands $(86 \%)$. It could be seen from the result that all these factors played a role or the other in influencing the farmers' ability in mitigating adverse climatic effects.

\begin{tabular}{l|c|c}
\multicolumn{2}{c}{ Table-6.Farmers' Perceived Constraints to Climate Change Variability. } \\
\hline Perceived Constraints & **Frequency & Relative Frequency \\
\hline Inadequate farmlands & 140 & 98.6 \\
\hline Inadequate capital & 142 & 94.4 \\
\hline Inadequate information on climate change & 134 & 61.9 \\
\hline High cost farm inputs & 88 & 92.3 \\
\hline Land fragmentations & 131 & 86.6 \\
\hline Erosion issues & 123 & 69.7 \\
\hline Constant deforestation & 99 & 15.5 \\
\hline Inadequate extension agents & 22 & 23.9 \\
\hline High cost of labour & 34 & 85.9 \\
\hline Long distance of farmlands & 122 & \\
\hline Note: ** Multiple Responses Recorded & & \\
\hline
\end{tabular}

Note: **Multiple Responses Recorded.

Source: Field survey, (2018).

\section{Conclusion and Recommendations}

The findings of the study revealed that the socio-economic factors played a major role in influencing the decision of the farmers in embracing adaptive strategies to checkmate the excesses of climatic variations in the area.The mean age of the farmers in the area is 50 years. This implies that the farmers are not too old to embrace adaptive measures in mitigating climate change incidence. The coefficient of age was also positive and significant at $5 \%$ level. This implies that as farmers' advances in age, their ability to adapt to climatic changes increases per time. The mean educational level of the farmers is 7 years which implies that the farmers attempted post primary education which exposes them to innovative ideas in handling climatic outcomes. Extension contacts proved to be the major source of information to the farmers on climate change. Results show that there is increasing rate of temperature, rainfall volume, sunshine hours and number of rainy days. This implies a high variability occurrence of climate change prevalent in the area. The adaptation techniques of the farmers were classified into highly sustainable adaptation strategies which include; use of pest and disease resistant varieties, use of organic fertilizers, tree planting, early information seeking on climate change etc and slightly sustainable; planting of different crop varieties, mulching, mixed cropping, etc. All the farmers in the area perceivedinadequate capital as a major constraint in combating climate change effects. Hence this study recommends government all levels to sensitize the crop farmers on the devastating effects of climate change on agriculture as well as provide supports where necessary to cushion its negative impacts.

\section{References}

[1] T. G. Apata, "Effects of global climate change on Nigerian agriculture: An empirical analysis," CBN Journal of Applied Statistics, vol. 2, pp. $31-45,2008$.

[2] E. E. Osuji, "Impacts of sustainable soil management techniques on land productivity and poverty levels of arable crop farmers in Imo State, Nigeria," Unpublished Ph.D Dissertation, Department of Agricultural Economics, Michael Okpara University of Agriculture Umudike, Nigeria, 2017.

[3] O. E. Ayinde, O. Ajewole, I. Ogunlade, and M. Adewumi, "Empirical analysis of agricultural production and climate change: A case study of Nigeria," Journal of Sustainable Development in Africa, vol. 12, pp. 275-283, 2010.

[4] T. G. Apata, K. D. Samuel, and A. O. Adeola, "Analysis of climate change perception and adaptation among arable food crop farmers in South Western Nigeria," presented at the Contributed Paper Prepared for Presentation at the International Association of Agricultural Economists' 2009 Conference, Beijing, China, August 16-22, 2009.pp. 12-19

[5] J. B. Robinson and D. Herbert, "Integrating climate change and sustainable development," International Journal of Global Environmental Issues, vol. 1, pp. 130-149, 2001.

[6] Building Nigeria's Response to Climate Change (BNRCC), presented at the 2008 Annual Workshop of Nigerian Environmental Study Team (NEST): The Recent Global and Local Action on Climate Change, held at Hotel Millennium, Abuja, Nigeria; 8-9th

October, 2008, pp. 14-23.
J. A. Schidhuber, "Global food security under climate change," in Proceedings of the National Academy of Sciences, Nigeria, 2007.

[8] M. Munasinghe, Climate change and sustainable development linkages: Points of departure. France: OECD 2001: Poverty Reduction: The DAC Guidelines, 2003.pp. 29-34.

[9] E. E. Osuji, U. G. Anyanwu, N. C. Ehirim, E. U. Eze, and A. Tim-Ashama, "Economics of processed cassava products in Imo State, Nigeria," Journal of Research in Business and Management, vol. 5, pp. 9-19, 2017.

[10] A. S. Oyekale, "Vulnerability of peasant cocoa farmers to climate change in South-West Nigeria," Journal of Human Ecology, vol. 40, pp. 33-41, 2012. Available at: https://doi.org/10.1080/09709274.2012.11906521.

[11] P. Obasi, A. Henri-Ukoha, I. Ukewuihe, and N. Chidiebere-Mark, "Factors affecting agricultural productivity among arable crop farmers in Imo State, Nigeria," American Journal of Experimental Agriculture, vol. 3, pp. 443-454, 2013. Available at: https://doi.org/10.9734/ajea/2013/2030.

[12] C. A. Nhemachena, "Micro level analysis of farmers adaptation to climate change in Southern Africa," IFPRI Discussion Paper No. O0714, Environment and Production Technology Division, Washington D.C, pp. 23-79, 2007.

[13] S. K. Juana, "Farmers perception of climate change and adaptation strategies," Journal of Geography and Regional Planing, vol. 1, pp. $138-143,2013$

[14] A. Henri-Ukoha and E. E. Osuji, "Determinants of arable crop farmers' use-levels of sustainable soil management techniques in Imo State, Nigeria," Nigerian Journal of Agriculture, Food and Environment, vol. 13, pp. 163-168, 2017.

[15] A. Egeru, "Role of indigenous knowledge in climate change adaptation," Indian Journal of Traditional Knowwledge, vol. 11, pp. 217 219, 2012.

[16] FME, National adaptation strategy and plan of action for climate change in Nigeria (NASPA-CCN). Abuja: Federal Ministry of Environment, Climate Change Department, 2011.pp.22-27. 